\title{
Viscera and muscle protein synthesis in neonatal pigs is increased more by intermittent bolus than by continuous feeding
}

\author{
Samer W. El-Kadi', María C. Gazzaneo', Agus Suryawan', Renán A. Orellana', Roberto Murgas Torrazza', Neeraj Srivastava', \\ Scot R. Kimball' ${ }^{2}$ Hanh V. Nguyen', Marta L. Fiorotto' and Teresa A. Davis ${ }^{1}$
}

BACKGROUND: Continuous and intermittent bolus orogastric feedings are strategies used in infants unable to tolerate normal feeds.

METHODS: To determine the effects of feeding modality on protein synthesis in different tissues, neonatal pigs received a balanced formula by orogastric tube as an intermittent bolus feed every $4 \mathrm{~h}$ or as a continuous infusion, or were fasted overnight.

RESULTS: As compared with fasting, protein synthesis in gastrocnemius, masseter, and soleus muscles; left ventricle; liver; pancreas; jejunum; and kidney increased in bolus- and continuously fed pigs, but the greatest increase occurred after a bolus meal. Tuberous sclerosis complex (TSC2), the proline-rich AKT substrate of $40 \mathrm{kDa}$ (PRAS40), eukaryotic initiation factor (elF) $4 E$ binding protein (4EBP1), and ribosomal protein 56 kinase 1 (S6K1) phosphorylation in all tissues, and the proportion of ribosomal protein $\mathbf{S} 4$ in liver polysomes were enhanced $90 \mathrm{~min}$ following the bolus meal but not immediately before the meal or during continuous feeding. Eukaryotic elongation factor 2 (eEF2) and elF2a phosphorylation were unaffected by feeding. CONCLUSION: These results suggest that intermittent bolus feeding increases protein synthesis in muscles of different fiber types and visceral tissues to a greater extent than continuous feeding by stimulating translation initiation.

M ore than $10 \%$ of newborns are of low birth weight, and many exhibit adverse long-term health problems $(1,2)$. There has been widely accepted recognition that adequate nutrition plays an important role in the survival and subsequent growth and development of low birth weight infants $(3,4)$. Orogastric tube feeding by continuous infusion or intermittent bolus delivery is necessary for neonates who are unable to coordinate oral food ingestion. Bolus feeding as compared with continuous feeding has been advocated to promote more normal feed-fast hormonal profiles and advance gastrointestinal development $(5,6)$. In some clinical studies, intermittent feeding has been reported to shorten the time required to reach full feeds, promote better feeding tolerance $(7,8)$, and produce a faster weight gain as compared with continuous feeding (8), although contrary results have also been published (9). Using the pig as a model for the human neonate, intermittent feeding as compared with continuous feeding has been shown to stimulate intestinal growth and development by increasing mucosal and intestinal protein mass (10). Despite these data, whether intermittent bolus and continuous feeding affect the regulation of growth in different organ systems has not been determined.

Rates of growth and protein turnover are at their highest during the neonatal period (11-14). Using the neonatal pig as a model of the human neonate, we have shown that feeding stimulates protein synthesis in skeletal muscle and visceral organs $(15,16)$. The response in muscle is regulated independently by the postprandial rise in insulin and amino acids (17), whereas in liver and other visceral tissues only amino acids are effective (18). Feeding increases protein synthesis through activation of translation initiation. There are two regulatory processes controlling translation initiation $(19,20)$; the first is mediated by eukaryotic initiation factor (eIF)-2 and involves the binding of initiator methionyl transfer RNA to the 40S ribosomal subunit to form the $43 \mathrm{~S}$ preinitiation complex. The second involves the activation of mammalian target of rapamycin (mTOR), which phosphorylates the eIF4E repressor protein, $4 \mathrm{E}$ binding protein 1 (4EBP1) and 70 $\mathrm{kDa}$ ribosomal protein S6 kinase 1 (S6K1), both of which regulate the binding of mRNA to the $43 \mathrm{~S}$ ribosomal complex. Activation of the mTOR by protein kinase B occurs in part through suppression of two inhibitors: tuberous sclerosis complex (TSC2) and the proline-rich AKT substrate of $40 \mathrm{kDa}$ (PRAS40) $(21,22)$. Insulin could also play a role in protein synthesis through dephosphorylation and deactivation of eukaryotic elongation factor 2 (eEF2), which controls peptide elongation (23).

Recently, we demonstrated that intermittent bolus feeding increases protein synthesis in fast-twitch glycolytic muscle to a greater extent than continuous feeding (24). However, no

'U.S. Department of Agriculture/Agricultural Research Service Children's Nutrition Research Center, Department of Pediatrics, Baylor College of Medicine, Houston, Texas; ${ }^{2}$ Department of Cellular and Molecular Physiology, Pennsylvania State University College of Medicine, Hershey, Pennsylvania. Correspondence: Teresa A. Davis (tdavis@bcm.edu) 
information is available on the impact of these different feeding modalities on the regulation of protein synthesis in muscles of different fiber types and vital organs. In the present study, the objectives were to determine whether intermittent bolus feeding as compared with continuous feeding enhanced protein synthesis in muscle of different fiber types and in vital organs, and to identify how feeding modalities affect the mTOR signaling pathway in these tissues.

\section{RESULTS}

\section{Plasma Branched-Chain Amino Acids and Insulin}

Circulating branched-chain amino acid and insulin concentrations over the entire feeding period were reported previously (24) and are presented in this article for reference. Branchedchain amino acid concentrations were highest in the $25.5 \mathrm{~h}$ bolus group $(P<0.05$; Figure 1$)$, whereas for the $24 \mathrm{~h}$ bolus group concentrations were similar to those in fasted pigs. Plasma branched-chain amino acid levels for the 24 and $25.5 \mathrm{~h}$ continuously fed pigs were intermediate between those in the overnight-fasted and those in the $25.5 \mathrm{~h}$ bolus-fed groups. Plasma insulin concentration was highest for the $25.5 \mathrm{~h}$ bolusfed pigs as compared with all other groups $(P<0.05)$.

\section{Protein Synthesis and mRNA Abundance in Liver Polysomes}

The rates of protein synthesis in the gastrocnemius, masseter, soleus, and cardiac muscles were significantly higher in the 24 and $25.5 \mathrm{~h}$ continuously fed and $24 \mathrm{~h}$ bolus groups as compared with the overnight-fasted group $(P<0.05$; Figure 2$)$. After
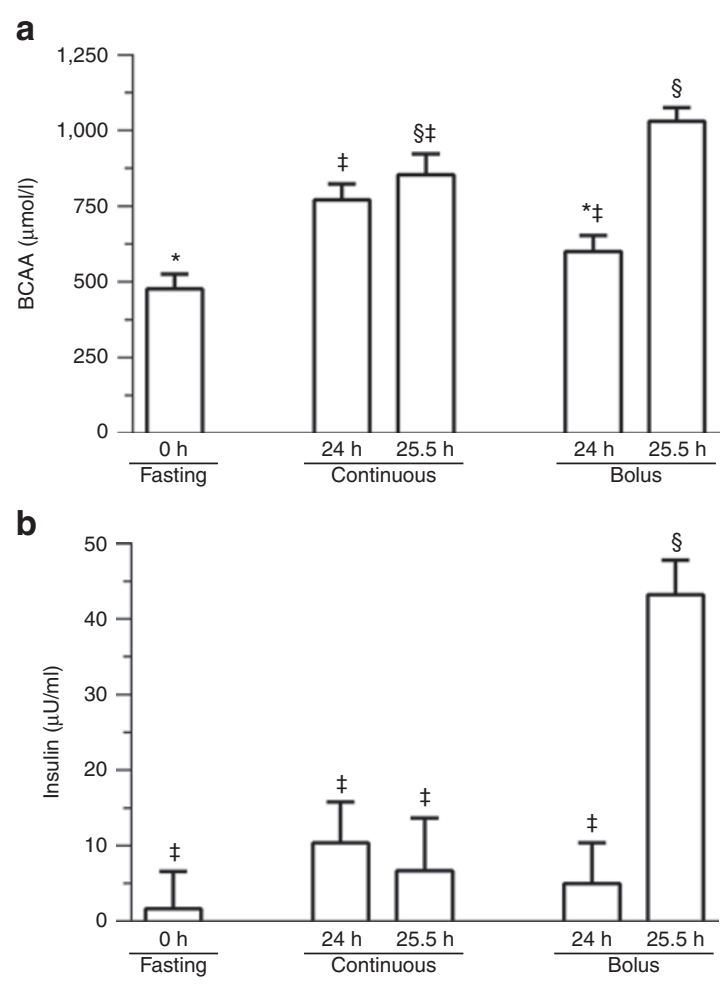

Figure 1. Concentrations of plasma (a) branched-chain amino acid (BCAA) and (b) insulin in pigs fasted overnight or fed continuously or by intermittent bolus for 24 or $25.5 \mathrm{~h}$. Values are means $\pm \mathrm{SEM}, n=5-7$. $*, \neq, \delta$ Values not sharing common symbols differ significantly $(P<0.05)$.
$25.5 \mathrm{~h}$ of bolus feeding ( $1.5 \mathrm{~h}$ after the last meal), protein synthesis rates in all muscles were greater as compared with the fasted group $(P<0.05)$, and greater $(P<0.05)$ than after $24 \mathrm{~h}$ of intermittent bolus feeding (just before the last meal) as well as after 24 and $25.5 \mathrm{~h}$ of continuous feeding $(P<0.05)$.

In the liver, jejunum, pancreas, and kidney, protein synthesis rates in all fed groups were higher than those in the fasted pigs $(P<0.05$; Figure 3$)$. In addition, protein synthesis rates in the bolus-fed group at $25.5 \mathrm{~h}$ were significantly higher than those of the bolus-fed group at $24 \mathrm{~h}(P<0.05)$. In the jejunum and kidney, rates of synthesis for the continuously fed pigs were similar to the $24 \mathrm{~h}$ bolus group; however, for the liver and pancreas, the synthesis rates for the continuously fed pigs were higher than those of the $24 \mathrm{~h}$ bolus group $(P<0.05)$. In the liver, jejunum, and pancreas, protein synthesis rates in the $25.5 \mathrm{~h}$ bolus-fed group were greater as compared with other feeding groups.

The proportion of rpS4 mRNA associated with polysomes in the liver was greater in the $25.5 \mathrm{~h}$ bolus-fed group as compared with other groups $(P<0.05$; Figure 4$)$. There were no differences in rpS4 abundance among fasting, 24 and $25.5 \mathrm{~h}$ continuous feeding, and $24 \mathrm{~h}$ bolus-fed groups. The distribution of hepatic ornithine decarboxylase mRNA in sucrose density gradients, a negative control for the regulation of the terminal oligopyrimidine (TOP) mRNA, was unchanged by treatments.

\section{Phosphorylation State of Signaling Components Leading to Protein Synthesis}

To ascertain the effect of feeding modality on the activation of upstream regulators of mTOR, the phosphorylation of TSC2 and PRAS40 was determined. TSC2 phosphorylation was greater in muscles and internal organs for the $25.5 \mathrm{~h}$ bolus group as compared with all other treatments $(P<0.05$; Table 1). Similarly, phosphorylation of PRAS40 was greater in the $25.5 \mathrm{~h}$ bolus-fed group as compared with all other groups $(P<0.05$; Table 2). The phosphorylation of 4EBP1 and S6K1, downstream effectors of mTORC1 and major players in translation initiation, were determined in all tissues. In gastrocnemius, soleus, masseter, left heart, jejunum, and kidney, the phosphorylation of $4 \mathrm{EBP} 1$ was greater for the $25.5 \mathrm{~h}$ bolus group as compared with all other groups $(P<0.05$; Table 3$)$. Phosphorylation of 4EBP1 did not differ between 24 and $25.5 \mathrm{~h}$ continuously fed, $24 \mathrm{~h}$ bolus-fed, and overnight-fasted groups in all muscles, jejunum, and kidney. However, 4EBP1 phosphorylation in liver and pancreas was greater for the 24 and $25.5 \mathrm{~h}$ continuously fed and $24 \mathrm{~h}$ bolus-fed groups than for the overnight-fasted group. For both tissues, 4EBP1 phosphorylation was greatest for the $25.5 \mathrm{~h}$ bolus group. In all tissues, phosphorylation of $56 \mathrm{~K} 1$ was greater for the $25.5 \mathrm{~h}$ bolus group as compared with all other groups $(P<0.05$; Figures 5 and 6 ). To determine the activation of the other arm of translation initiation and peptide elongation, the phosphorylation of eIF $2 \alpha$ and eEF2 were determined. In all tissues, neither eIF2 $\alpha$ phosphorylation nor eEF2 phosphorylation were affected by treatments (Tables 4 and 5). 


\section{Articles | El-Kadietal.}
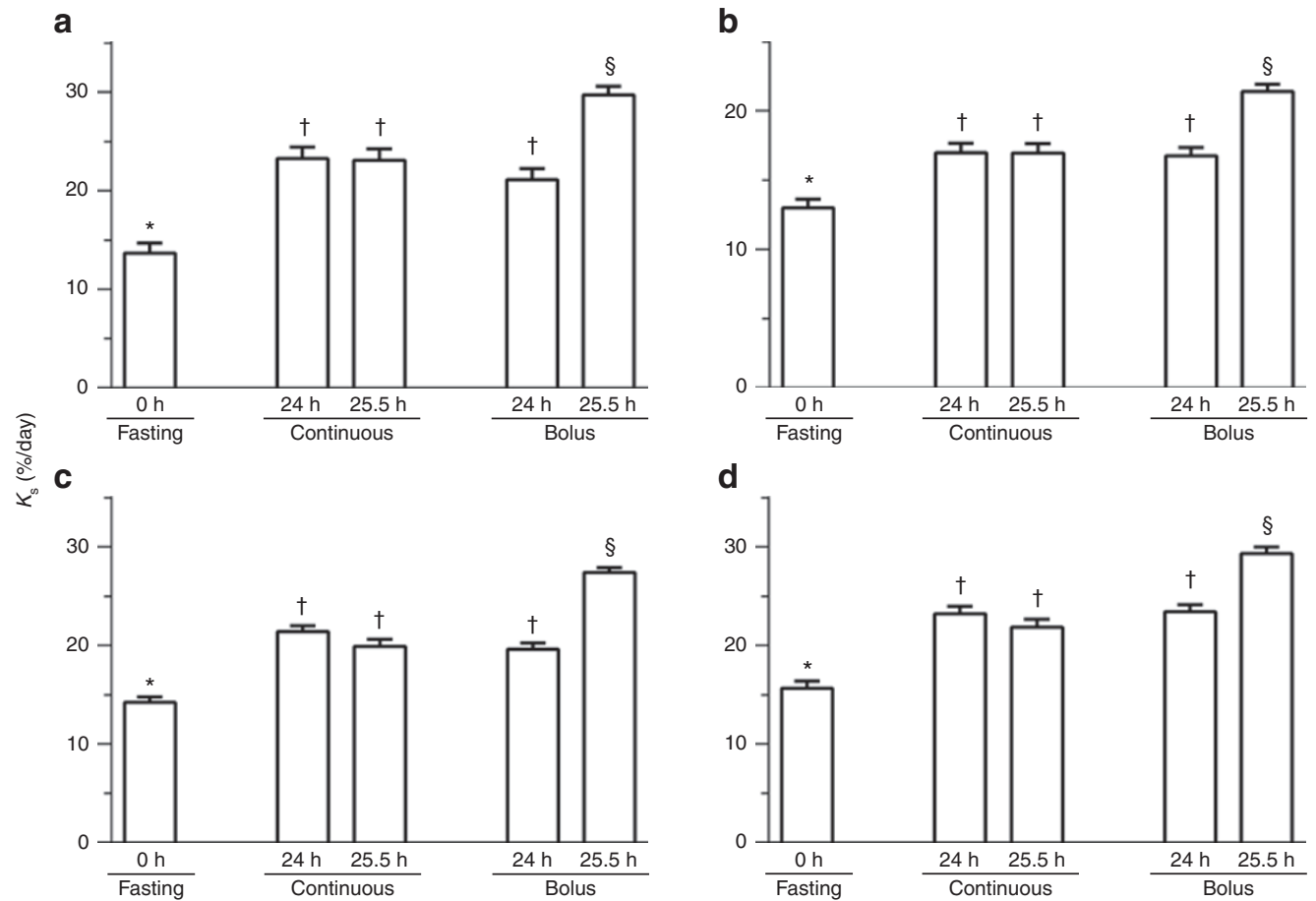

Figure 2. Protein synthesis in the (a) gastrocnemius, (b) masseter, (c) soleus, and (d) left ventricle of pigs fasted overnight or fed continuously or by intermittent bolus for 24 or $25.5 \mathrm{~h}$. $K_{s^{\prime}}$ fractional protein synthesis in \%/day. Values are mean $\pm \mathrm{SEM}, n=5-7$. ${ }^{*,+, s}$ Values not sharing common symbols differ significantly $(P<0.05)$.

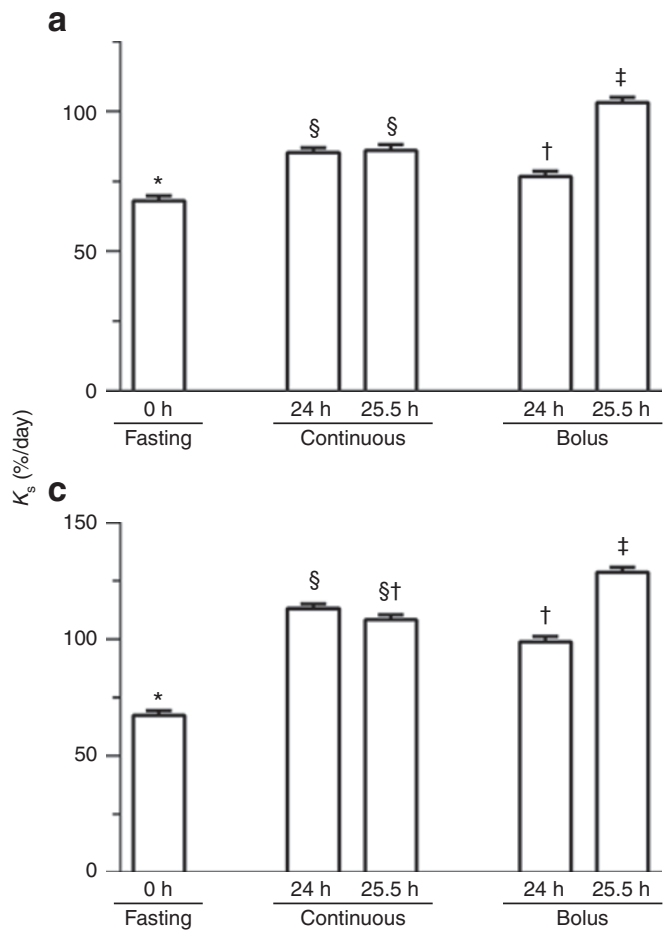

b

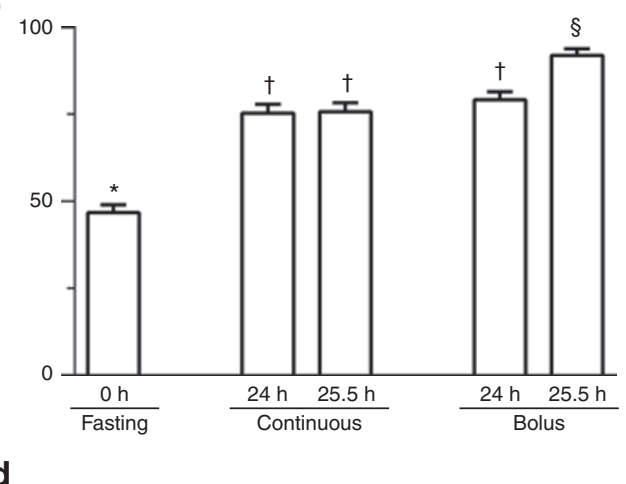

d

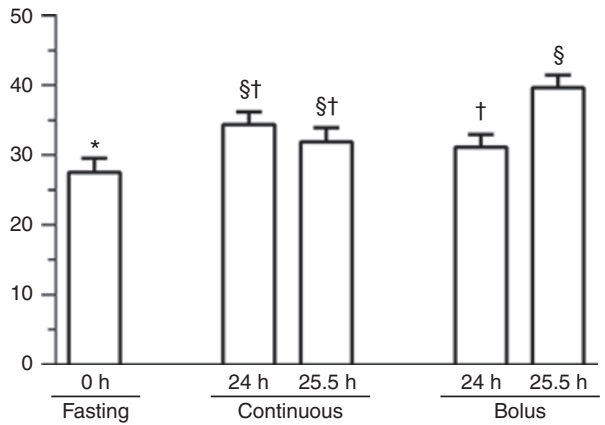

Figure 3. Protein synthesis in the (a) liver, (b) jejunum, (c) pancreas, and (d) kidney of pigs fasted overnight or fed continuously or by intermittent bolus for 24 or $25.5 \mathrm{~h}$. $K_{s^{\prime}}$ fractional protein synthesis in \%/day. Values are mean $\pm \mathrm{SEM}, n=5-7$. ${ }^{*,+, \neq, 5}$ Values not sharing common symbols differ significantly $(P<0.05)$.

\section{DISCUSSION}

The adequacy of continuous vs. intermittent bolus feeding to sustain optimal growth rates remains controversial despite much research in this area (25). This is in part caused by confounders such as disease state, duration of stay in the hospital, and parenteral nutrient delivery, which limit clinical studies (25). The piglet is used in nutritional studies as a model for the human neonate due to our ability to vary only one factor 
at a time and use invasive approaches to measure protein synthesis in vivo in the piglet. These studies are clinically relevant because few data are available to describe the mechanisms controlling protein synthesis under continuous and intermittent feeding. Previously, we have shown that intermittent feeding as compared with continuous feeding enhanced protein synthesis in the longissimus dorsi muscle (26). Given that the protein

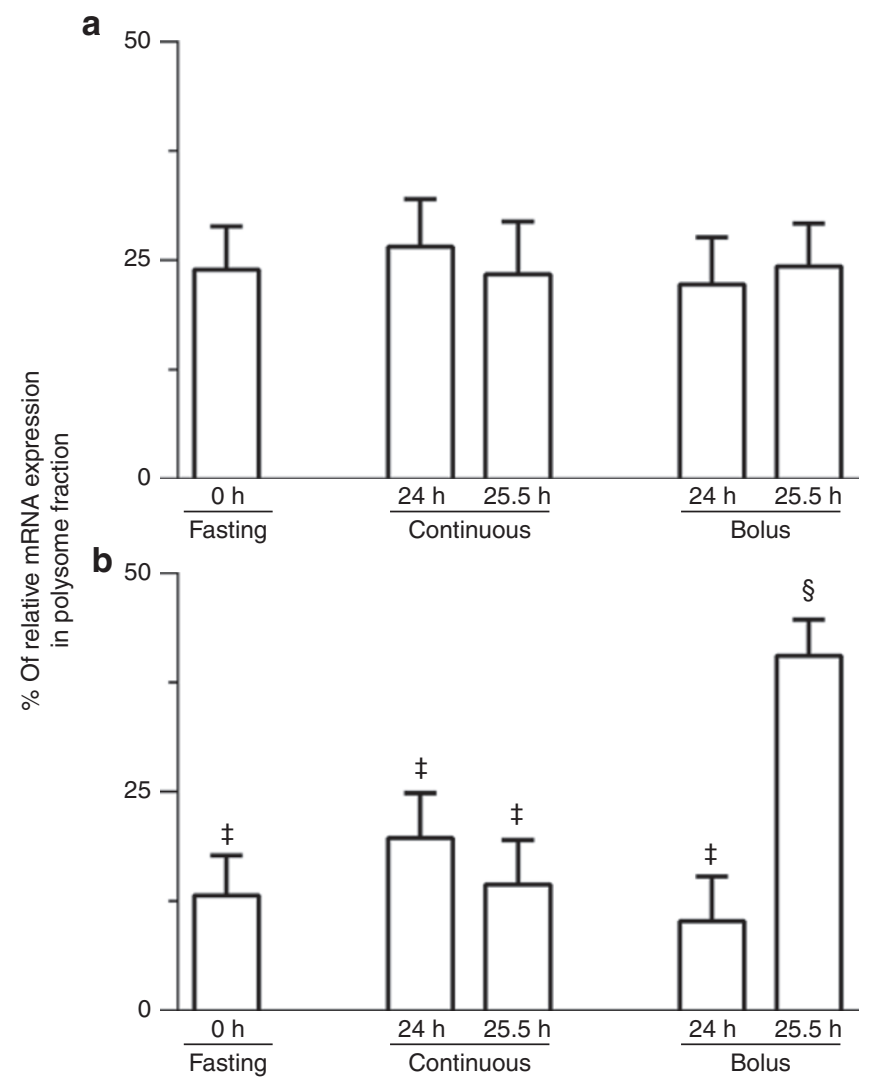

Figure 4. The proportion of (a) ornithine decarboxylase (ODC) and (b) ribosomal protein S4 (rpS4) mRNAs in the polysomal fraction in the liver of pigs fasted overnight or fed continuously or by intermittent bolus for 24 or $25.5 \mathrm{~h}$. Values are mean $\pm \mathrm{SEM}, n=5-7$. $\neq$, VValues not sharing common symbols differ significantly $(P<0.05)$. synthesis response to nutritional stimuli may vary with muscle type (11) and in viscera (16), the aim of this study was to determine the effects of feeding modalities on protein synthesis in different muscle types and also in internal organs.

There is a paucity of data comparing feeding frequency and its effect on growth and protein synthesis in neonates. Results from one human study suggest that protein deposition was similar in infants fed intermittently or continuously (27). In that study, however, nitrogen deposition was determined by net balance, which may not be sufficiently sensitive to measure subtle changes in protein deposition over a short period $(28,29)$. In the current study, protein synthesis increased in all muscle types, ranging from those that contain primarily glycolytic fibers to those with mainly oxidative fibers, and internal organs in response to feeding and the response was highest $1.5 \mathrm{~h}$ following a meal in those pigs that had been fed intermittently. Although we have previously reported differences in protein synthesis among different muscle types (26), it is likely that those differences represent only acute responses following $4 \mathrm{~h}$ of enteral feeding, whereas in the current study the differences in responses were diminished following more prolonged feeding of $24 \mathrm{~h}$. The increased protein synthesis in the jejunum is consistent with the findings of a previous study in which intermittent feeding was shown to stimulate intestinal growth and development in newborn piglets by increasing mucosal and intestinal protein mass as compared with continuous feeding (10).

We have previously shown, using the pancreatic-substrate clamp, that insulin and amino acids independently stimulate protein synthesis in skeletal muscle (17), but that the response in visceral tissue is primarily driven by amino acids (16). Postprandial protein synthesis rates following a meal paralleled the rapid rise in blood insulin and amino acid levels and returned to prefeeding rates by $4 \mathrm{~h}$ (26). In the current study, the greater increase in protein synthesis in the intermittent bolus-fed as compared with continuous-fed pigs was associated with more profound changes in circulating insulin and amino acids. As the increase in protein synthesis with feeding occurred in visceral tissues as well as in muscle, it seems likely

Table 1. Phosphorylation of TSC2 in muscles and visceral tissues of pigs fasted overnight or fed continuously or by intermittent bolus for 24 or $25.5 \mathrm{~h}$

\begin{tabular}{|c|c|c|c|c|c|}
\hline \multirow[b]{2}{*}{ Tissue } & \multirow{2}{*}{$\begin{array}{c}\text { Fasting } \\
\mathrm{Oh}\end{array}$} & \multicolumn{2}{|c|}{ Continuous } & \multicolumn{2}{|c|}{ Bolus } \\
\hline & & $24 \mathrm{~h}$ & $25.5 \mathrm{~h}$ & $24 \mathrm{~h}$ & $25.5 \mathrm{~h}$ \\
\hline Gastrocnemius & $0.37 \pm 0.08^{\mathrm{a}}$ & $0.47 \pm 0.07^{\mathrm{a}}$ & $0.57 \pm 0.08^{\mathrm{a}}$ & $0.45 \pm 0.06^{\mathrm{a}}$ & $0.88 \pm 0.06^{b}$ \\
\hline Masseter & $0.28 \pm 0.11^{\mathrm{a}}$ & $0.28 \pm 0.10^{\mathrm{a}}$ & $0.24 \pm 0.11^{\mathrm{a}}$ & $0.35 \pm 0.09^{\mathrm{a}}$ & $0.87 \pm 0.08^{b}$ \\
\hline Left heart & $0.42 \pm 0.09^{\mathrm{a}}$ & $0.49 \pm 0.09^{\mathrm{a}}$ & $0.49 \pm 0.10^{\mathrm{a}}$ & $0.48 \pm 0.09^{\mathrm{a}}$ & $0.92 \pm 0.08^{b}$ \\
\hline Jejunum & $0.20 \pm 0.09^{\mathrm{a}}$ & $0.35 \pm 0.09^{\mathrm{a}}$ & $0.27 \pm 0.10^{\mathrm{a}}$ & $0.28 \pm 0.09^{\mathrm{a}}$ & $0.82 \pm 0.08^{b}$ \\
\hline Pancreas & $0.35 \pm 0.07^{\mathrm{a}}$ & $0.32 \pm 0.07^{\mathrm{a}}$ & $0.38 \pm 0.08^{\mathrm{a}}$ & $0.36 \pm 0.07^{a}$ & $0.87 \pm 0.06^{b}$ \\
\hline Kidney & $0.27 \pm 0.10^{\mathrm{a}}$ & $0.32 \pm 0.10^{\mathrm{a}}$ & $0.29 \pm 0.11^{\mathrm{a}}$ & $0.33 \pm 0.10^{\mathrm{a}}$ & $0.85 \pm 0.09^{b}$ \\
\hline
\end{tabular}

Values are mean \pm SEM in arbitrary units, $n=5-7$ per group. 


\section{Articles | El-Kadiet al.}

Table 2. Phosphorylation of PRAS40 in muscles and visceral tissues of pigs fasted overnight or fed continuously or by intermittent bolus for 24 or $25.5 \mathrm{~h}$

\begin{tabular}{|c|c|c|c|c|c|}
\hline \multirow[b]{2}{*}{ Tissue } & \multirow{2}{*}{$\begin{array}{c}\text { Fasting } \\
\mathrm{Oh}\end{array}$} & \multicolumn{2}{|c|}{ Continuous } & \multicolumn{2}{|c|}{ Bolus } \\
\hline & & $24 \mathrm{~h}$ & $25.5 \mathrm{~h}$ & $24 \mathrm{~h}$ & $25.5 \mathrm{~h}$ \\
\hline Gastrocnemius & $0.35 \pm 0.08^{\mathrm{a}}$ & $0.41 \pm 0.08^{\mathrm{a}}$ & $0.46 \pm 0.09^{a}$ & $0.42 \pm 0.08^{\mathrm{a}}$ & $0.93 \pm 0.07^{b}$ \\
\hline Masseter & $0.46 \pm 0.08^{\mathrm{a}}$ & $0.47 \pm 0.08^{\mathrm{a}}$ & $0.45 \pm 0.09^{\mathrm{a}}$ & $0.53 \pm 0.08^{\mathrm{a}}$ & $0.88 \pm 0.07^{b}$ \\
\hline Left heart & $0.22 \pm 0.09^{\mathrm{a}}$ & $0.23 \pm 0.09^{\mathrm{a}}$ & $0.24 \pm 0.10^{\mathrm{a}}$ & $0.32 \pm 0.09^{a}$ & $0.87 \pm 0.07^{b}$ \\
\hline Jejunum & $0.35 \pm 0.08^{\mathrm{a}}$ & $0.38 \pm 0.08^{\mathrm{a}}$ & $0.40 \pm 0.09^{a}$ & $0.38 \pm 0.08^{\mathrm{a}}$ & $0.91 \pm 0.07^{b}$ \\
\hline Pancreas & $0.43 \pm 0.06^{\mathrm{a}}$ & $0.52 \pm 0.06^{\mathrm{a}}$ & $0.51 \pm 0.07^{a}$ & $0.54 \pm 0.06^{\mathrm{a}}$ & $0.93 \pm 0.05^{b}$ \\
\hline Kidney & $0.26 \pm 0.09^{\mathrm{a}}$ & $0.31 \pm 0.09^{\mathrm{a}}$ & $0.35 \pm 0.10^{\mathrm{a}}$ & $0.29 \pm 0.09^{\mathrm{a}}$ & $0.89 \pm 0.07^{b}$ \\
\hline
\end{tabular}

Values are mean \pm SEM in arbitrary units, $n=5-7$ per group.

PRAS40, proline-rich AKT substrate of $40 \mathrm{kDa}$.

a,bvalues in a row not sharing common symbols differ significantly $(P<0.05)$.

Table 3. Phosphorylation of 4EBP1 in muscles and visceral tissues of pigs fasted overnight or fed continuously or by intermittent bolus for 24 or $25.5 \mathrm{~h}$

\begin{tabular}{|c|c|c|c|c|c|}
\hline \multirow[b]{2}{*}{ Tissue } & \multirow{2}{*}{$\begin{array}{c}\text { Fasting } \\
\mathrm{Oh}\end{array}$} & \multicolumn{2}{|c|}{ Continuous } & \multicolumn{2}{|c|}{ Bolus } \\
\hline & & $24 \mathrm{~h}$ & $25.5 \mathrm{~h}$ & $24 \mathrm{~h}$ & $25.5 \mathrm{~h}$ \\
\hline Gastrocnemius & $0.04 \pm 0.07^{\mathrm{a}}$ & $0.24 \pm 0.07^{\mathrm{a}}$ & $0.26 \pm 0.07^{\mathrm{a}}$ & $0.22 \pm 0.06^{\mathrm{a}}$ & $0.83 \pm 0.06^{b}$ \\
\hline Masseter & $0.05 \pm 0.07^{\mathrm{a}}$ & $0.23 \pm 0.07^{\mathrm{a}}$ & $0.23 \pm 0.07^{\mathrm{a}}$ & $0.22 \pm 0.06^{\mathrm{a}}$ & $0.84 \pm 0.06^{b}$ \\
\hline Left heart & $0.12 \pm 0.11^{\mathrm{a}}$ & $0.46 \pm 0.09^{a}$ & $0.47 \pm 0.11^{\mathrm{a}}$ & $0.36 \pm 0.09^{a}$ & $0.90 \pm 0.08^{b}$ \\
\hline Jejunum & $0.10 \pm 0.09^{\mathrm{a}}$ & $0.36 \pm 0.08^{\mathrm{a}}$ & $0.37 \pm 0.09^{\mathrm{a}}$ & $0.43 \pm 0.08^{\mathrm{a}}$ & $0.78 \pm 0.07^{b}$ \\
\hline Pancreas & $0.16 \pm 0.09^{\mathrm{a}}$ & $0.59 \pm 0.08^{b, c}$ & $0.61 \pm 0.09^{b, c}$ & $0.60 \pm 0.08^{b}$ & $0.93 \pm 0.08^{c}$ \\
\hline Kidney & $0.06 \pm 0.09^{\mathrm{a}}$ & $0.26 \pm 0.08^{\mathrm{a}}$ & $0.23 \pm 0.09^{a}$ & $0.23 \pm 0.08^{\mathrm{a}}$ & $0.81 \pm 0.07^{b}$ \\
\hline
\end{tabular}

Values are mean \pm SEM in arbitrary units, $n=5-7$ per group.

4EBP1, 4E binding protein.

$a, b, c$ Values in a row not sharing common symbols differ significantly $(P<0.05)$.

that the increase in protein synthesis is at least in part due to the feeding-induced elevation in amino acids in the current study. Our studies also have shown that meal feeding increases protein synthesis by enhancing the activation of translation initiation, a process regulated by mTOR $(26,30-32)$.

Protein synthesis is controlled by three regulatory mechanisms. The first involves eIF2, which facilitates the binding of methionyl-tRNA to the $40 \mathrm{~S}$ ribosomal subunit, forming the $43 \mathrm{~S}$ preinitiation complex $(19,20)$. We have previously shown that the increased protein synthesis in response to feeding occurs independently of any changes in the phosphorylation of the $\alpha$-subunit of eIF2 $(24,33)$, which is in agreement with the current findings in both continuously and intermittently fed pigs.

The second process involves the binding of the active mRNA to the $43 \mathrm{~S}$ preinitiation complex, facilitated by the eIF4G•eIF4E complex, a downstream effector of mTOR. The activation of the mTOR signaling pathway following a meal occurs through phosphorylation of protein kinase $\mathrm{B}$, which phosphorylates and inactivates the allosteric inhibitors of
mTOR, TSC1, and PRAS40 $(21,22,34)$. In this study, the phosphorylation of protein kinase B target proteins, TSC2 and PRAS40, increased $1.5 \mathrm{~h}$ following a meal, probably due to the rise in insulin $(33,35)$. When activated, mTOR phosphorylates the downstream target proteins, S6K1 and $4 \mathrm{EBP} 1$, leading to the dissociation of the eIF4E $4 \mathrm{EBP} 1 \mathrm{com}$ plex and the formation of the active eIF4G.eIF4E complex, which enhances translation initiation. In the current study, S6K1 and 4EBP1 phosphorylation increased $1.5 \mathrm{~h}$ following the meal in the intermittently fed pigs but was not different from fasting either immediately before the meal or when pigs had been fed continuously at both time points for all tissues measured. Therefore, our data support our hypothesis that intermittent bolus meal feeding enhances protein synthesis through activation of translation initiation in all muscle types, including the heart, and in vital organs, probably due to an increase in the activation of the insulin and/ or amino acid signaling pathways. The modest elevation in tissue protein synthesis in continuously fed as compared with fasting pigs that occurs despite the lack of stimulation 


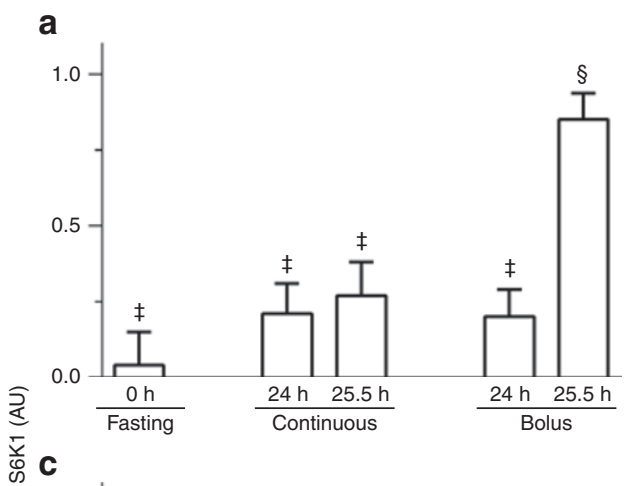

b
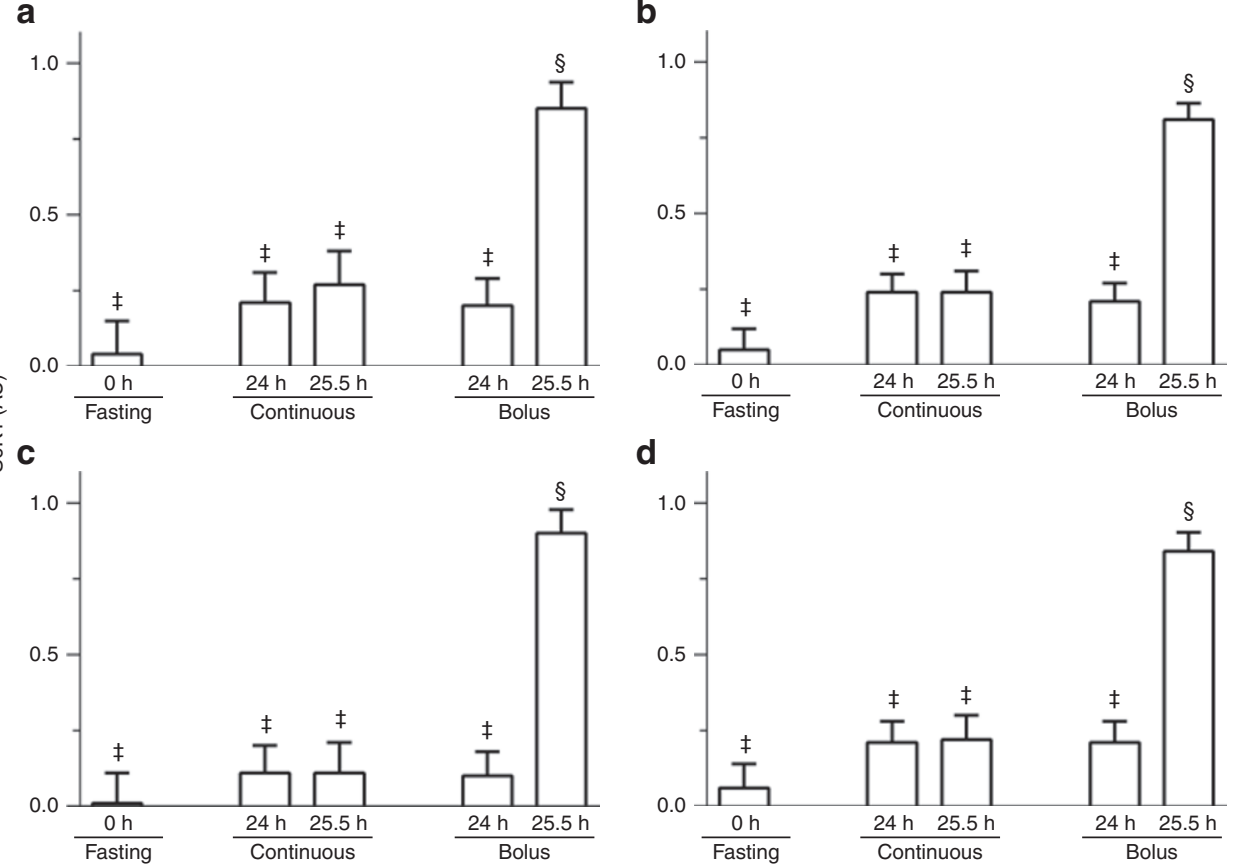

d

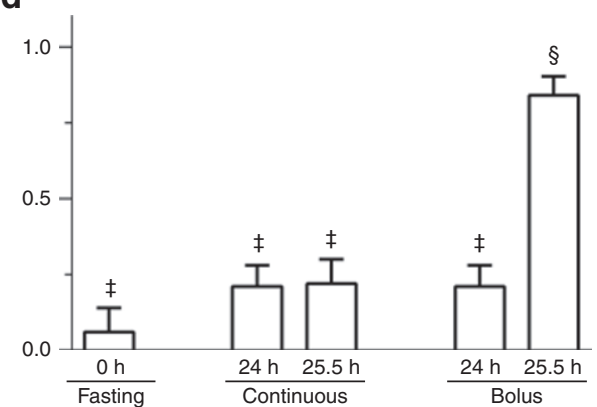

Figure 5. Ribosomal protein $\mathrm{S} 6$ kinase 1 (S6K1) phosphorylation in the (a) gastrocnemius, (b) masseter, (c) soleus, and (d) left heart of pigs fasted overnight or fed continuously or by intermittent bolus for 24 or $25.5 \mathrm{~h}$. Values are mean $\pm \mathrm{SEM}, n=5-7$. $\$$, VValues not sharing common symbols differ significantly $(P<0.05)$. AU, arbitrary units.
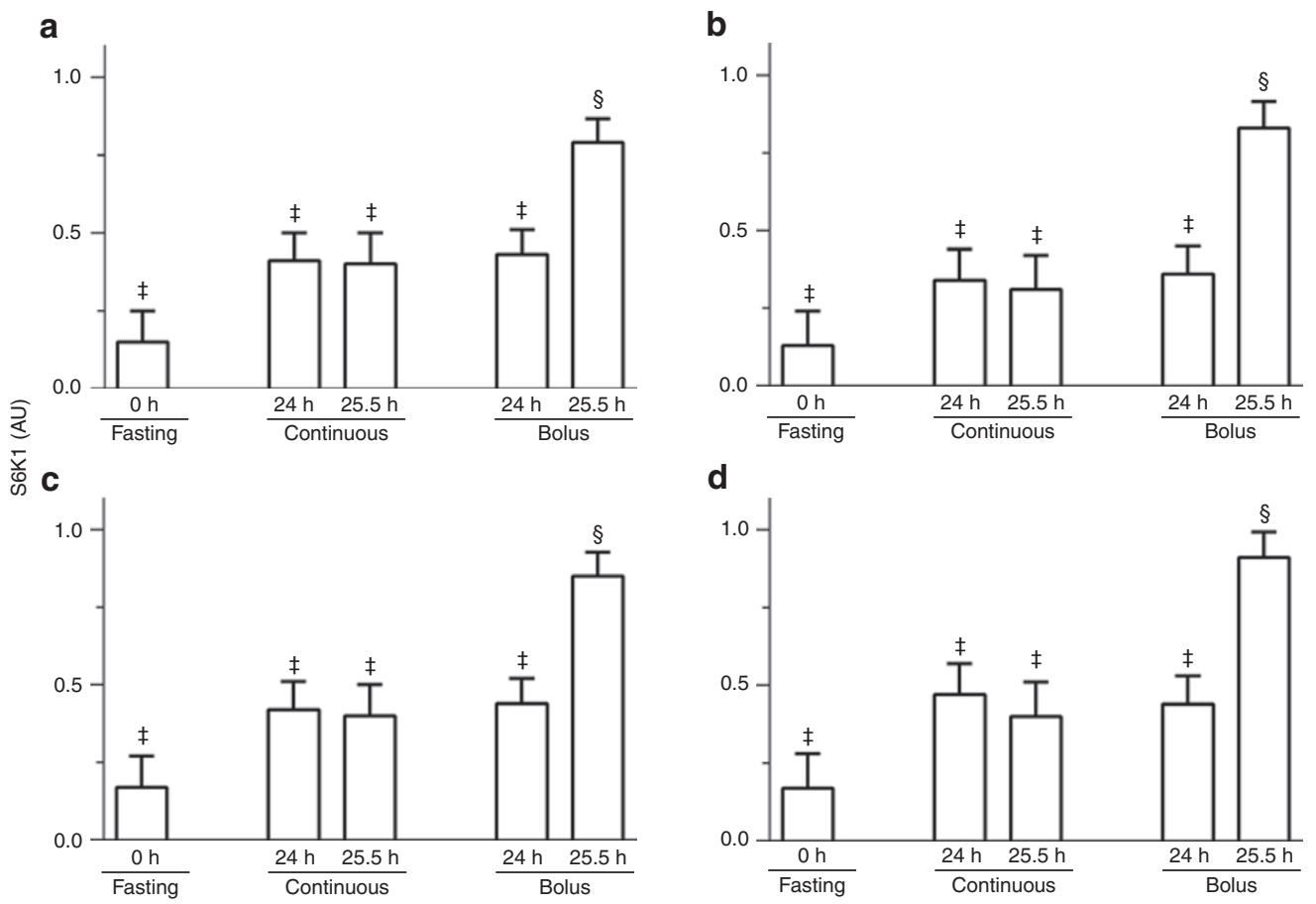

Figure 6. Ribosomal protein S6 kinase 1 (S6K1) phosphorylation in the (a) liver, (b) jejunum, (c) pancreas, and (d) kidney of pigs fasted overnight or fed continuously or by intermittent bolus for 24 or $25.5 \mathrm{~h}$. Values are mean $\pm \mathrm{SEM}, n=5-7 . \neq$, SValues not sharing common symbols differ significantly $(P<0.05)$. AU, arbitrary units.

of biomarkers of translation initiation may be due to an upregulation of reinitiation that is probably not mediated by this pathway (36).

The third process regulating protein synthesis is peptide elongation. Although phosphorylation of eEF2 can enhance peptide elongation in vitro (23), we have previously shown that under normal physiologic conditions in vivo, peptide elongation mediated by eEF2 phosphorylation does not change $(24,33)$. The results of the current study show no effect of feeding on eEF2 phosphorylation and support our 


\section{Articles | El-Kadiet al.}

Table 4. Phosphorylation of elF2a in muscles and visceral tissues of pigs fasted overnight or fed continuously or by intermittent bolus for 24 or $25.5 \mathrm{~h}$

\begin{tabular}{|c|c|c|c|c|c|}
\hline \multirow[b]{2}{*}{ Tissue } & \multirow{2}{*}{$\begin{array}{c}\text { Fasting } \\
\mathrm{Oh}\end{array}$} & \multicolumn{2}{|c|}{ Continuous } & \multicolumn{2}{|c|}{ Bolus } \\
\hline & & $24 \mathrm{~h}$ & $25.5 \mathrm{~h}$ & $24 \mathrm{~h}$ & $25.5 \mathrm{~h}$ \\
\hline Gastrocnemius & $0.79 \pm 0.14$ & $0.88 \pm 0.13$ & $0.73 \pm 0.14$ & $0.90 \pm 0.12$ & $0.83 \pm 0.11$ \\
\hline Masseter & $0.74 \pm 0.15$ & $0.73 \pm 0.14$ & $0.76 \pm 0.15$ & $0.70 \pm 0.13$ & $0.71 \pm 0.12$ \\
\hline Left heart & $0.80 \pm 0.15$ & $0.66 \pm 0.14$ & $0.85 \pm 0.15$ & $0.69 \pm 0.13$ & $0.66 \pm 0.12$ \\
\hline Jejunum & $0.71 \pm 0.20$ & $0.70 \pm 0.18$ & $0.76 \pm 0.20$ & $0.85 \pm 0.16$ & $0.80 \pm 0.15$ \\
\hline Pancreas & $0.77 \pm 0.20$ & $0.84 \pm 0.18$ & $0.76 \pm 0.20$ & $0.86 \pm 0.16$ & $0.81 \pm 0.15$ \\
\hline Kidney & $0.61 \pm 0.13$ & $0.67 \pm 0.12$ & $0.75 \pm 0.13$ & $0.71 \pm 0.11$ & $0.67 \pm 0.10$ \\
\hline
\end{tabular}

Values are mean \pm SEM in arbitrary units, $n=5-7$ per group. No significant differences were detected.

elF2a, eukaryotic initiation factor 2a.

Table 5. Phosphorylation of eEF2 in muscles and visceral tissues of pigs fasted overnight or fed continuously or by intermittent bolus for 24 or $25.5 \mathrm{~h}$

\begin{tabular}{|c|c|c|c|c|c|}
\hline \multirow[b]{2}{*}{ Tissue } & \multirow{2}{*}{$\begin{array}{c}\text { Fasting } \\
0 \mathrm{~h}\end{array}$} & \multicolumn{2}{|c|}{ Continuous } & \multicolumn{2}{|c|}{ Bolus } \\
\hline & & $24 \mathrm{~h}$ & $25.5 \mathrm{~h}$ & $24 \mathrm{~h}$ & $25.5 \mathrm{~h}$ \\
\hline Gastrocnemius & $0.65 \pm 0.13$ & $0.64 \pm 0.12$ & $0.83 \pm 0.13$ & $0.67 \pm 0.11$ & $0.64 \pm 0.10$ \\
\hline Masseter & $0.75 \pm 0.14$ & $0.77 \pm 0.13$ & $0.76 \pm 0.14$ & $0.71 \pm 0.12$ & $0.77 \pm 0.11$ \\
\hline Left heart & $0.71 \pm 0.18$ & $0.78 \pm 0.16$ & $0.69 \pm 0.18$ & $0.79 \pm 0.15$ & $0.75 \pm 0.14$ \\
\hline Jejunum & $0.95 \pm 0.24$ & $0.91 \pm 0.22$ & $0.74 \pm 0.24$ & $0.81 \pm 0.20$ & $0.86 \pm 0.18$ \\
\hline Pancreas & $0.65 \pm 0.24$ & $0.84 \pm 0.21$ & $0.68 \pm 0.24$ & $0.65 \pm 0.20$ & $0.79 \pm 0.18$ \\
\hline Kidney & $0.76 \pm 0.16$ & $0.84 \pm 0.15$ & $0.82 \pm 0.16$ & $0.71 \pm 0.13$ & $0.78 \pm 0.12$ \\
\hline
\end{tabular}

Values are mean \pm SEM in arbitrary units, $n=5-7$ per group. No significant differences were detected.

eEF2, eukaryotic elongation factor 2.

previous findings that protein synthesis is mainly controlled by translation initiation rather than by peptide elongation.

Transcripts of genes involved in the synthesis and control of ribosomal proteins contain a TOP tract at the $5^{\prime}$-end of the transcript (37). Ribosomal protein S4 is a TOP gene that encodes a component of the $40 \mathrm{~S}$ ribosomal subunit $(38,39)$. Because only mRNAs associated with polysomes are translated $(40,41)$, the distribution of the TOP mRNA between polysomal and nonpolysomal fractions correlates with active mRNA translation, and therefore protein synthesis. Previously, we showed that in response to meal feeding there was a temporal increase in the proportion of rpS4 mRNA in polysomes with a concurrent increase in protein synthesis (26). In the current study, the proportion of rpS4 mRNA associated with polysomes was higher in livers from pigs fed intermittently $1.5 \mathrm{~h}$ after a meal than in those fed continuously or intermittently just before the meal. Although feeding stimulates protein synthesis in the liver, using hyperinsulinemic-euglycemic amino acid clamps, we have shown that amino acids, but not insulin, can enhance protein synthesis in the liver (15). Likewise, oral administration of leucine simultaneously increased the proportion of hepatic rpS4 mRNA associated with polysomes and enhanced protein synthesis (42). Suppression of S6K1 phosphorylation by rapamycin inhibits $5^{\prime} \mathrm{TOP}$ mRNA translation (37). Therefore, it is likely that the mechanism by which rpS4 translation is enhanced by intermittent feeding is through activation of the mTOR target, $\mathrm{S} 6 \mathrm{~K} 1$, and is mediated by amino acids.

The results of the current study showed that intermittent bolus as compared with continuous feeding increased protein synthesis in skeletal and cardiac muscles and in several vital organs of the neonatal pig. This increase occurred in association with activation of the mTOR signaling pathway and the subsequent enhanced phosphorylation of S6K1 and 4EBP1. In the liver, the enhanced protein synthesis occurred through greater translation of TOP mRNA encoding for ribosomal proteins possibly via activation of the mTOR pathway. These results suggest that intermittent bolus feeding as compared with continuous feeding enhances tissue protein synthesis through increased activation of amino acid and insulin-induced translation initiation and by biogenesis of ribosomal proteins. As the intermittent bolus pattern of feeding as compared with continuous feeding enhanced protein synthesis similarly in all muscles and visceral tissues studied, the results suggest that 
intermittent bolus feeding may promote symmetric growth in neonates. The results of this study are of direct relevance for infants and children who are on parenteral nutrition and not tolerating full feeds, and/or those who are continuously fed via orogastric or nasogastric tube due to feeding intolerance. Furthermore, studies are needed to determine whether the intermittent bolus pattern of feeding, as compared with continuous feeding, will enhance lean body mass and weight gain in neonates.

\section{METHODS}

\section{Animals and Design}

The protocol was approved by the Animal Care and Use Committee of Baylor College of Medicine and was conducted in accordance with the National Research Council's Guide for the Care and Use of Laboratory Animals. Sows and piglets were housed and managed as previously described (26). After birth, piglets resided with their sow and were not given supplemental creep feed. Piglets were studied at $5-7 \mathrm{~d}$ of age and at a weight of $2.0 \pm 0.4 \mathrm{~kg}$.

Under general anesthesia and using sterile techniques, catheters were inserted into an external jugular vein and common carotid artery $3 \mathrm{~d}$ before infusion, as described previously (26). After recovering from anesthesia, piglets were returned to their respective sows until the day of study.

\section{Treatments and Infusion}

Treatments were randomly assigned to piglets using a completely randomized design. The five treatment groups ( $n=5-7$ per treatment) were (i) overnight fasted, (ii) intermittently bolus fed for $24 \mathrm{~h}$, (iii) intermittently bolus fed for $25.5 \mathrm{~h}$, (iv) continuously fed for $24 \mathrm{~h}$, and (v) continuously fed for $25.5 \mathrm{~h}$. Briefly, piglets assigned to the intermittent bolus-fed groups were enterally fed by gavage $(40 \mathrm{ml} / \mathrm{kg}$ body wt) a balanced enteral milk replacement every $4 \mathrm{~h}$ over a 15 -min period and were killed at either $24 \mathrm{~h}$ ( $4 \mathrm{~h}$ after the last meal and just before a new meal) or $25.5 \mathrm{~h}$ ( $1.5 \mathrm{~h}$ after the last meal). We have previously shown (26) that the postprandial rise in translation initiation signaling and protein synthesis is sustained from at least $0.5-2 \mathrm{~h}$ but falls to baseline by $4 \mathrm{~h}$ after a meal. Therefore, we opted to sample just before and $1.5 \mathrm{~h}$ after the last meal. The milk replacer contained $5 \%$ whey protein concentrate, $1 \%$ lactose, and 6.5\% fat, providing 192 $\mathrm{kcal}, 10 \mathrm{~g}$ protein, and $13 \mathrm{~g}$ fat per $\mathrm{kg}$ of body weight. The continuously fed groups received the same balanced enteral milk replacement at a rate of $10 \mathrm{ml} / \mathrm{kg}$ body $\mathrm{wt} / \mathrm{h}$ maintained constant throughout the infusion period until the piglets were killed 24 or $25.5 \mathrm{~h}$ later to allow for direct comparison in time with the bolus-fed groups. The overnight food-deprived piglets were killed at $0 \mathrm{~h}$. Intermittent bolus-fed and continuously fed pigs were provided the same amount of food over a $24 \mathrm{~h}$ period.

\section{Tissue Protein Synthesis In Vivo}

Tissue protein synthesis was measured using a flooding dose of $\mathrm{L}-\left[4-{ }^{3} \mathrm{H}\right]$ phenylalanine $(43)$. Piglets received L- $\left[4-{ }^{3} \mathrm{H}\right]$ phenylalanine ( $1.5 \mathrm{mmol} / \mathrm{kg}$ body wt, $0.5 \mathrm{mCi} / \mathrm{kg}$ body wt; Amersham Bioscience, Piscataway, NJ) injected $30 \mathrm{~min}$ before they were killed. Samples were obtained from the gastrocnemius, masseter, and soleus muscles, left heart, liver, jejunum, pancreas, and kidney, and were immediately frozen in liquid nitrogen and stored at $-70^{\circ} \mathrm{C}$ until analyzed (43).

\section{Reverse Transcriptase and Real-Time Quantitative PCR}

The proportion of ribosomal protein S4 (rpS4) and ornithine decarboxylase mRNAs in the polysomal fraction was determined in the liver as described previously (26).

\section{Protein Immunoblot Analysis}

Equal amounts of extracted protein from the muscle and visceral tissue homogenates were separated by electrophoresis on polyacrylamide gels. For each assay, all samples were run at the same time on triple-wide gels (C.B.S. Scientific, Del Mar, CA) to minimize interassay variation. Proteins were electrophoretically transferred to polyvinlidene difluoride transfer membranes (Pall, Port Washington, NY), incubated with appropriate primary antibodies, washed, and exposed to an appropriate secondary antibody (31).

Immunoblots that were probed with antiphospho-specific antibodies were normalized by stripping the blots in stripping buffer and then reprobed with corresponding nonphospho-specific antibodies (Pierce Biotechnology, Rockford, IL). Immunoblotting was performed using the following primary antibodies: TSC2 (total and $\mathrm{Thr}^{1462}$; Cell Signaling, Danvers, MA), PRAS40 (total and Thr ${ }^{246}$; Cell Signaling), 4EBP1 (total; Bethyl Laboratories, Montgomery, TX and $\mathrm{Thr}^{70}$; Cell Signaling), S6K1 (total and $\mathrm{Thr}^{398}$; Cell Signaling), eIF2 $\alpha$ (total and Ser ${ }^{51}$; Cell Signaling), and eEF2 (total and Thr $r^{56}$; Cell Signaling). Blots were developed using an enhanced chemiluminescence kit (GE Health Sciences, Buckinghamshire, UK), visualized, and analyzed using a ChemiDoc-It Imaging System (UVP, Upland, CA).

\section{Calculations and Statistics}

The fractional rate of protein synthesis ( $K_{\mathrm{s}}(\% /$ day), percentage of protein mass synthesized in a day) was calculated as $K_{\mathrm{s}}=\left[\left(S_{\mathrm{b}} / S_{\mathrm{a}}\right) \times\right.$ $(1,440 / t)] \times 100$, where $S_{\mathrm{b}}(\mathrm{dpm} / \mathrm{nmol})$ is the specific radioactivity of the protein-bound phenylalanine, $S_{a}(\mathrm{dpm} / \mathrm{nmol})$ is the specific radioactivity of the tissue free phenylalanine at the time of tissue collection, corrected by linear regression with the blood-specific radioactivity of the animal against time, $t$ is the time of labeling in minutes, and 1,440 is for minutes-to-day conversion.

Statistical analysis was carried out using the MIXED procedure of SAS (SAS Institute, Cary, NC), using one-way ANOVA to determine main statistical differences between groups. When a significant effect was detected, all means were compared using the Tukey-Kramer multiple-comparison test. Data are presented as least square means \pm SEM, and differences are considered significant at $P \leq 0.05$.

\section{ACKNOWLEDGMENTS}

We thank Robert Shulman and Douglas Burrin for helpful discussions, Rosemarie Almonaci and Sue Koo for technical assistance, Jerome Stubblefield for animal care, and E. O'Brian Smith for statistical assistance.

\section{STATEMENT OF FINANCIAL SUPPORT}

This work was supported by National Institutes of Health grant R01 AR44474 and U.S. Department of Agriculture/Agricultural Research Service grant 6250-510000-055.

\section{Disclosure: The authors declare no conflict of interest.}

\section{REFERENCES}

1. Ehrenkranz RA. Early, aggressive nutritional management for very low birth weight infants: what is the evidence? Semin Perinatol 2007; 31: $48-55$.

2. Saigal S, Stoskopf BL, Streiner DL, Burrows E. Physical growth and current health status of infants who were of extremely low birth weight and controls at adolescence. Pediatrics 2001;108:407-15.

3. Marchand, V. Enteral nutrition tube feedings. In: Baker S, Baker RD, Davis A, eds. Pediatric Nutrition Support. Sudbury, MA: Jones and Bartlett Publishers, 2007:249-60.

4. Nutritional needs of the preterm infant. In: Kleinman RE, ed. Pediatric Nutrition Handbook, 5th edn. Elk Grove Village, IL: American Academy of Pediatrics, 2003:23-54.

5. Aynsley-Green A. The endocrinology of feeding in the newborn. Baillieres Clin Endocrinol Metab 1989;3:837-68.

6. Mashako MN, Bernard C, Cezard JP, Chayvialle JA, Navarro J. Effect of total parenteral nutrition, constant rate enteral nutrition, and discontinuous oral feeding on plasma cholecystokinin immunoreactivity in children. J Pediatr Gastroenterol Nutr 1987;6:948-52.

7. Dollberg S, Kuint J, Mazkereth R, Mimouni FB. Feeding tolerance in preterm infants: randomized trial of bolus and continuous feeding. J Am Coll Nutr 2000;19:797-800.

8. Schanler RJ, Shulman RJ, Lau C, Smith EO, Heitkemper MM. Feeding strategies for premature infants: randomized trial of gastrointestinal priming and tube-feeding method. Pediatrics 1999;103:434-9. 
9. Dsilna A, Christensson K, Alfredsson L, Lagercrantz H, Blennow M. Continuous feeding promotes gastrointestinal tolerance and growth in very low birth weight infants. J Pediatr 2005;147:43-9.

10. Shulman RJ, Redel CA, Stathos TH. Bolus versus continuous feedings stimulate small-intestinal growth and development in the newborn pig. J Pediatr Gastroenterol Nutr 1994;18:350-4.

11. Davis TA, Fiorotto ML, Nguyen HV, Reeds PJ. Protein turnover in skeletal muscle of suckling rats. Am J Physiol 1989;257(5 Pt 2):R1141-6.

12. Denne SC, Rossi EM, Kalhan SC. Leucine kinetics during feeding in normal newborns. Pediatr Res 1991;30:23-7.

13. Goldspink DF, Kelly FJ. Protein turnover and growth in the whole body, liver and kidney of the rat from the foetus to senility. Biochem J 1984;217:507-16.

14. Lewis SE, Kelly FJ, Goldspink DF. Pre- and post-natal growth and protein turnover in smooth muscle, heart and slow- and fast-twitch skeletal muscles of the rat. Biochem J 1984;217:517-26.

15. Davis TA, Fiorotto ML, Beckett PR, et al. Differential effects of insulin on peripheral and visceral tissue protein synthesis in neonatal pigs. Am J Physiol Endocrinol Metab 2001;280:E770-9.

16. Suryawan A, O'Connor PM, Bush JA, Nguyen HV, Davis TA. Differential regulation of protein synthesis by amino acids and insulin in peripheral and visceral tissues of neonatal pigs. Amino Acids 2009;37:97-104.

17. O'Connor PM, Kimball SR, Suryawan A, et al. Regulation of translation initiation by insulin and amino acids in skeletal muscle of neonatal pigs. Am J Physiol Endocrinol Metab 2003;285:E40-53.

18. O'Connor PM, Kimball SR, Suryawan A, et al. Regulation of neonatal liver protein synthesis by insulin and amino acids in pigs. Am J Physiol Endocrinol Metab 2004;286:E994-E1003.

19. Ma XM, Blenis J. Molecular mechanisms of mTOR-mediated translational control. Nat Rev Mol Cell Biol 2009;10:307-18.

20. Sonenberg N, Hinnebusch AG. Regulation of translation initiation in eukaryotes: mechanisms and biological targets. Cell 2009;136:731-45.

21. Huang J, Manning BD. A complex interplay between Akt, TSC2 and the two mTOR complexes. Biochem Soc Trans 2009;37(Pt 1):217-22.

22. Wang $\mathrm{H}$, Zhang $\mathrm{Q}$, Wen $\mathrm{Q}$, et al. Proline-rich Akt substrate of $40 \mathrm{kDa}$ (PRAS40): a novel downstream target of PI3k/Akt signaling pathway. Cell Signal 2012;24:17-24.

23. Wang X, Li W, Williams M, Terada N, Alessi DR, Proud CG. Regulation of elongation factor 2 kinase by p90(RSK1) and p70 S6 kinase. EMBO J 2001;20:4370-9.

24. Gazzaneo MC, Suryawan A, Orellana RA, et al. Intermittent bolus feeding has a greater stimulatory effect on protein synthesis in skeletal muscle than continuous feeding in neonatal pigs. J Nutr 2011;141:2152-8.

25. Premji SS, Chessell L. Continuous nasogastric milk feeding versus intermittent bolus milk feeding for premature infants less than 1500 grams. Coch Database Syst Rev 2011:CD001819.

26. Gazzaneo MC, Orellana RA, Suryawan A, et al. Differential regulation of protein synthesis and mTOR signaling in skeletal muscle and visceral tissues of neonatal pigs after a meal. Pediatr Res 2011;70:253-60.
27. Silvestre MA, Morbach CA, Brans YW, Shankaran S. A prospective randomized trial comparing continuous versus intermittent feeding methods in very low birth weight neonates. J Pediatr 1996;128:748-52.

28. Bier DM. Intrinsically difficult problems: the kinetics of body proteins and amino acids in man. Diabetes Metab Rev 1989;5:111-32.

29. Tomé D, Bos C. Dietary protein and nitrogen utilization. J Nutr 2000;130:1868S-73S.

30. Frank JW, Escobar J, Suryawan A, et al. Protein synthesis and translation initiation factor activation in neonatal pigs fed increasing levels of dietary protein. J Nutr 2005; 135:1374-81.

31. Frank JW, Escobar J, Suryawan A, et al. Dietary protein and lactose increase translation initiation factor activation and tissue protein synthesis in neonatal pigs. Am J Physiol Endocrinol Metab 2006;290:E225-33.

32. Wilson FA, Suryawan A, Orellana RA, et al. Feeding rapidly stimulates protein synthesis in skeletal muscle of neonatal pigs by enhancing translation initiation. J Nutr 2009;139:1873-80.

33. Suryawan A, Orellana RA, Nguyen HV, Jeyapalan AS, Fleming JR, Davis TA. Activation by insulin and amino acids of signaling components leading to translation initiation in skeletal muscle of neonatal pigs is developmentally regulated. Am J Physiol Endocrinol Metab 2007;293: E1597-605.

34. Davis TA, Fiorotto ML. Regulation of muscle growth in neonates. Curr Opin Clin Nutr Metab Care 2009;12:78-85.

35. Suryawan A, Davis TA. The abundance and activation of mTORC1 regulators in skeletal muscle of neonatal pigs are modulated by insulin, amino acids, and age. J Appl Physiol 2010;109:1448-54.

36. Martineau Y, Derry MC, Wang X, et al. Poly(A)-binding protein-interacting protein 1 binds to eukaryotic translation initiation factor 3 to stimulate translation. Mol Cell Biol 2008;28:6658-67.

37. Jefferies HB, Fumagalli S, Dennis PB, Reinhard C, Pearson RB, Thomas G. Rapamycin suppresses 5'TOP mRNA translation through inhibition of p70s6k. EMBO J 1997;16:3693-704.

38. Sherton CC, Wool IG. Determination of the number of proteins in liver ribosomes and ribosomal subunits by two-dimensional polyacrylamide gel electrophoresis. J Biol Chem 1972;247:4460-7.

39. Wool IG, Chan YL, Paz V, Olvera J. The primary structure of rat ribosomal proteins: the amino acid sequences of L27a and L28 and corrections in the sequences of S4 and S12. Biochim Biophys Acta 1990;1050:69-73.

40. Kimball SR, Jefferson LS. Control of protein synthesis by amino acid availability. Curr Opin Clin Nutr Metab Care 2002;5:63-7.

41. Kimball SR, Jefferson LS. Regulation of global and specific mRNA translation by oral administration of branched-chain amino acids. Biochem Biophys Res Commun 2004;313:423-7.

42. Anthony JC, Anthony TG, Kimball SR, Jefferson LS. Signaling pathways involved in translational control of protein synthesis in skeletal muscle by leucine. J Nutr 2001;131:856S-60S.

43. Davis TA, Burrin DG, Fiorotto ML, Nguyen HV. Protein synthesis in skeletal muscle and jejunum is more responsive to feeding in 7-than in 26-dayold pigs. Am J Physiol 1996;270(5 Pt 1):E802-9. 